\title{
E-SERVICES: EFFICIENCY AND USE IN MODERN BUSINESS
}

\section{Maja Obradović, Maja Kljajić, \\ Ana Obradović, Marko Pavićević}

\section{Singidunum University,} Belgrade, Serbia

Correspondence:

Maja Obradović

e-mail:

mobradovic@singidunum.ac.rs

\begin{abstract}
:
The accelerated development of the Internet and information technologies has conditioned the emergence of new forms of business. One of the most important types of the application of new technologies is electronic business (eBusiness). The term eBusiness is a general term for the electronic way of doing business. This paper will provide an overview of the development and advantages of using electronic business in today. The importance of the service sector in the Republic of Serbia is also evidenced by data showing the share of various sectors in domestic GDP. The service sector generates over 50\% of GDP in Republic of Serbia. The importance of the global service economy, the strengthening of the service sector and the support of information technologies have conditioned the emergence and development of eServices. Therefore, special attention in this paper will be paid to examples from the field of eServices of the public and private sector of the Republic of Serbia. Even though some efforts have been made to develop eBusiness and eServices, additional efforts need to be made to educate and inform natural and legal persons about the use and advantages of these services.
\end{abstract}

Keywords:

electronic business, eServices, Internet, eBanking, mBanking.

\section{INTRODUCTION}

The increase in the use of the Internet in the daily performance of activities and communication between the company and users has brought a new, modern form of business. Changes in the needs and habits of consumers and the development of technologies on the other hand have conditioned the development of electronic business as a modern type of business. Availability of information, wide range of products and services, time saving and disappearance of spatial barriers are just some of the advantages recognized by users. In order to use all advantages of electronic business, it is necessary to harmonize information and communication technologies and strategically adjust to the goals and technological achievements [1]. The intensive transition from traditional to modern ways of doing business, from the aspect of finance, requires 
certain capital expenditures. It is necessary to provide funds for financing the implementation of the software solution, its testing and maintenance, as well as training of employees so that the entire process runs smoothly.

The development of new technologies and the application of the Internet in everyday business enables more efficient performance of activities. Electronic business (eBusiness) refers to the performance of various transactions in electronic form, via the Internet, which enables more efficient performance of daily business activities [2]. At the same time, it represents a general concept that includes all forms of business transactions or exchange of information in the free market that are performed by using the information and communication technology [3].

The legislative framework of eBusiness in the territory of the Republic of Serbia is the Law on Electronic Document, Electronic Identification and Trust Services in Electronic Business [2]. According to the abovementioned Law, electronic business is defined as the use of data in electronic form, means of electronic communication and electronic data processing in the performance of activities of natural and legal persons.

If adequately organised, eBusiness can bring a series of benefits to companies. Some of the advantages of eBusiness are reflected in simpler and faster access to information, efficient and effective use of available resources, easier and safer data exchange, faster processing of collected data, greater security of data storage and generally greater time savings of all stakeholders in the eBusiness process.

According to the Strategy for Development of the Information Society in the Republic of Serbia till 2020, the plan is that citizens will be able to make all contacts with administrative bodies, holders of public authority, courts and the health care system, without leaving their apartment, i.e. workplace, except for those contacts that require physical presence [4].

The increasing participation of the service sector in advanced economies causes special attention and provides many opportunities to modern users. According to [5], the share of services/service sector in the total GDP of the Republic of Serbia in 2018 was $51.02 \%$. This data indicates the importance of the service sector in our country. In order for the service process to be successfully realized, it is necessary to monitor and understand the needs and behaviour of users during the service process. An important component in the provision of e-services is real-time response [6]. The success of eservice delivery depends on the set strategies, the choice of an adequate method for measuring performance, as well as raising awareness and better understanding of the concept of electronic service [6]. Different forms of using eBusiness and their advantages have been recognized in both the private and public sectors. Further in this paper, an overview of the current examples of eServices in the Republic of Serbia will be presented.

\section{ESERVICES IN THE REPUBLIC OF SERBIA}

According to [7], eService is defined as a service that is available via the Internet, and which enables the execution of tasks, solving problems or doing transactions. Both legal and natural persons can be eService users. Some of the important areas of successful application of the Internet and new technologies in the service sector that are applied in the territory of the Republic of Serbia will be presented further in the text:

\section{1. eBanking}

Modern business conditions in the field of banking have transformed the traditional system of delivering services to the population. Therefore, today financial institutions provide their services through various channels, such as branch banking, ATMs, internet banking (eBanking) and mobile banking (mBanking).

Electronic banking (eBanking) is a fast, secure, simple and efficient electronic service that allows an access to a bank account, but also the provision of Internet services, 24 hours a day and 7 days a week [8] . The main goal of electronic banking is faster and safer connection of clients and information. This form of banking can be realized by using the Internet, but with other specialized computer networks. Business efficiency is achieved by lower costs, as well as by a better competitive position in the business market, which in eBusiness is achieved through the use of wireless communication devices, namely: mobile phones, Palm OS devices and Pocket \& Handheld PCs.

The main advantages of using the eBanking system are reflected in the following:

- time saving;

- lower commissions for all online payments;

- two-way communication with clients;

- reduction of operating costs;

- smaller volume of paper documentation;

- payment on the go;

- faster and simpler cash flow; 
- the possibility to perform transactions from different geographical distances;

- current account balance overview;

- current review of all payment transactions.

Disadvantages of using the eBanking system relate to:

- business security;

- lack of legislation;

- lack of privacy;

- alienation;

- aversion to innovations;

- danger of data misuse;

- identity theft.

\section{2. mBanking}

The development of information technology has enabled financial institutions to revolutionize the patterns of providing their services. Mobile banking (m-banking) is the fastest growing and most profitable channel for providing banking services [9]. Mobile banking is any transaction with a monetary amount, which is performed by the use of mobile networks. The basic characteristics of mobile banking are reflected in time availability, device mobility, savings of time and resources, simplicity of operations and security.

The reasons that led to the development of different types of mobile services, including mobile banking, are the following:

- developed mobile telephony market;

- rapid development of the Internet and e-commerce;

- possibilities of authentication and authorization in different types of transactions;

- new principles of charging for different services.

\section{3. eGovernment}

The eGovernment portal was created with the idea of enabling the citizens of the Republic of Serbia to quickly and efficiently solve their administrative tasks without physically going to the government counter. The Law on Electronic Administration defines the tasks performed by the administration of state bodies and organizations, bodies and organizations of the provincial autonomy, bodies and organizations of local self-government units, institutions, public enterprises, special bodies through which the regulatory function is exercised and legal and natural persons entrusted with public authorities by using information and communication technologies [10]. The manner of work of the eGovernment portal is regulated by the Government of the Republic of Serbia.

eGovernment is defined as a central place for providing electronic services to three categories of users, namely: citizens, economy and state. For each of the above stated categories, there is a defined range of electronic services whose idea is to enable simpler and faster execution of various administrative tasks.

eGovernment portal started working in June 2010 in the territory of the Republic of Serbia. It is the result of the work of a large number of different state institutions and some local self-governments that have made available their electronic services and the necessary information related to the services they provide to citizens and the economy. [11] Based on the report of the Statistical Office of the Republic of Serbia, an overview of the movement of the number of Internet service users in the Republic of Serbia in the period from 2010 to 2019 was made. Within the users of Internet services, the tendency of the movement of the number of users of eGovernment in the Republic of Serbia is separately shown. Having in mind that the eGovernment portal started operating in 2010, a graphic presentation of the movement of users of this service for that period will be presented below.

Table 1. NUMBER OF USER OF PUBLIC ADMINISTRATION ELECTRONIC SERVICES

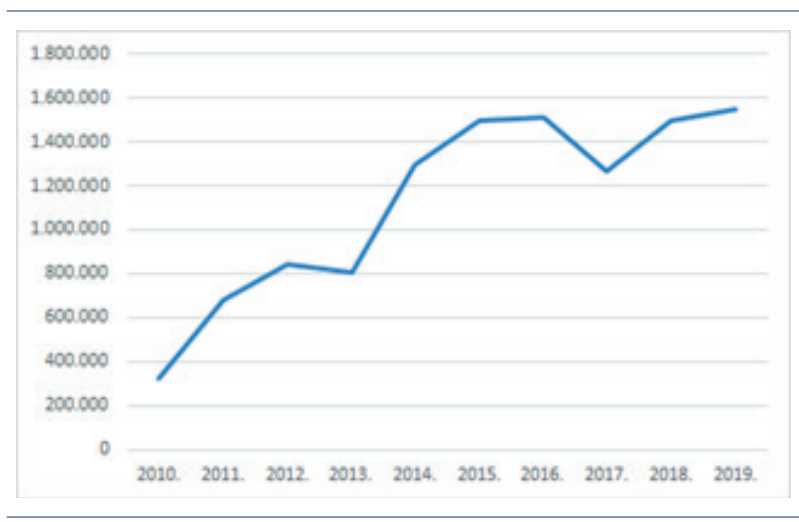

Source: Statistical Office of the Republic of Serbia, https://www.stat.gov.rs/

Based on the previous chart, there is a noticeable increase in the number of users of electronic service of eGovernment in the observed period in the Republic of Serbia. The number of users today, compared to 2010, when the implementation of eGovernment started in Serbia, is almost five times higher, which indicates the 
recognition of the importance and significance of the implementation of the eGovernment portal by the users of this service.

Further development is defined by the eGovernment Development Programme as a public policy document by which the Government of the Republic of Serbia plans the development of eGovernment in the Republic of Serbia, and which is defined for the period from 2019 to 2022. The programme plans public policy measures along with the harmonization of this document with the goals of public administration development goals set by the Public Administration Reform Strategy in the Republic of Serbia and continuity in the implementation of measures for eGovernment development in the Republic of Serbia for the period 2015-2018. [12]

The e-Government Development Index (EGDI) is used as a parameter for measuring the success of eGovernment development and ranking of countries. This index is used to rank countries that are members of the United Nations. The EGDI consists of three important dimensions of e-government - provision of online services, telecommunication connectivity and human capacity. [13] Below is an overview of EGDI trends in the Republic of Serbia and countries in the region (Bosnia and Herzegovina, Bulgaria, Montenegro, Croatia, Hungary, Romania, Northern Macedonia, Slovenia) for the period 2010-2020. The value of the EGDI index ranges from 0 to 1 so that better ranked countries have values closer to 1 and it is calculated every two years.

\section{Table 2. E-GOVERNMENT DEVELOPMENT INDEX}

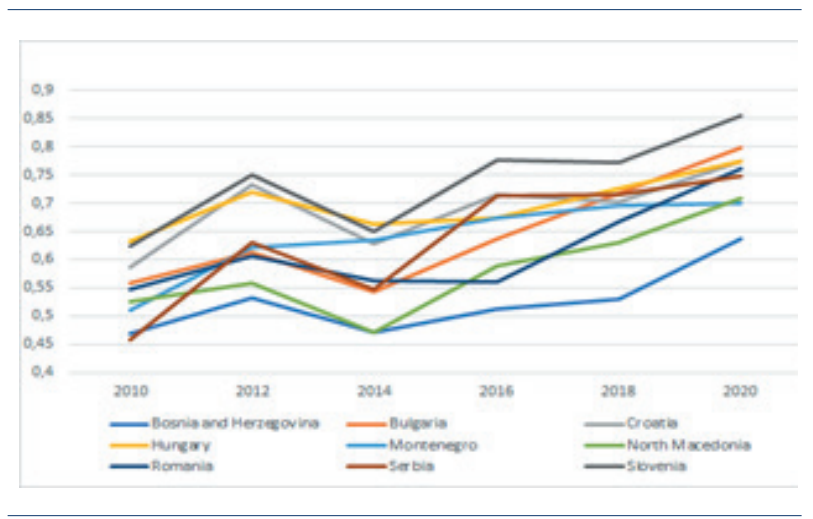

Source: UN E-Government Knowledgebase,

https://publicadministration.un.org/egovkb/en-us/data-center

When it comes to the Republic of Serbia, in 2010, when the implementation of eGovernment began in our country, we had the worst rank, i.e. the lowest value of the EGDI index taking into account the observed countries from the region. By observing all UN member states, in 2010, Serbia was 81st on the ranking list of 193 UN member states using this index. The latest data from 2020 show that Serbia is currently ranked 58th with the EGDI index of 0.7474, which is the largest index that the Republic of Serbia had in the observed period.

The eGovernment Development Programme in the Republic of Serbia is designed to be implemented in compliance with certain principles. One of the basic principles of this programme is the principle of environmental protection, which implies the gradual complete abolition of the use of paper.

\section{4. eTourist}

A new eTourist platform has been created within the eGovernment portal. The Ministry of Trade, Tourism and Telecommunications has created the eTourist platform with the idea of a central information system in the tourism and hospitality industry.

The Law on Hospitality regulates the conditions and manner of performing hospitality activities, in nautical tourism facilities and hunting tourism facilities, residence fee and penalties, as well as other issues important for their development and improvement. [14] According to the [14], central information system in the field of hospitality industry and tourism of public administration electronic services (eTourist) is defined as the unique and centralized electronic information system, which contains all relevant data on accommodation providers and accommodation facilities, through which their records is kept and other data derived from the hospitality, nautical and hunting tourism, i.e. tourism activities or services in tourism industry.

A great advantage of such a centralized system is reflected in the unification of all data from hospitality employee and accommodation facilities in the Republic of Serbia. The benefits of the eTourist can be viewed from different angles, such as: hospitality employee, consumers i.e. tourists and the state institution and the tourist organization point of view.

The characteristics of the centralized information system are reflected in the following: it is free, with an easy and fast access to the system, it facilitates business, and it is important in the segment of hotel systems integration.

After the full implementation of the eTurist system, numerous benefits for the users of this system are expected. From the point of view of hospitality employee, some of the advantages mentioned are simplification of procedures for registration of domestic and foreign 
tourists, simplification of administrative procedures, online submission of requests for categorization. From perspective of tourists, some of the benefits are related to the security, accommodation in legal accommodation facilities and higher quality of service. Benefits of the eTourist implementation from the perspective of the state are reflected in monitoring data such as: total number of tourists who visited the country, their geographical and demographic characteristics in real time, daily insight into the database containing information about accommodation facilities and accommodation service providers and promotion of Serbia as a tourist destination [15].

The full implementation and launching of the eTourist were planned for April 2020. Due to the spread of the COVID-19 pandemic, the launch of the e-Tourist central information system has been fully postponed [16].

\section{CONCLUSION}

An integral part of the business of today's companies are the constant changes that are occurring in the market. The turbulent environment influences companies to be innovative and proactively oriented in everyday business. In order to successfully perform their activities and place their products and services companies need to adequately adapt to the new changes.

The importance of electronic business has gained special significance in the past period. Global business and the spread of the COVID-19 pandemic have influenced the creation of new and improvement of the existing products and services. Although they bring benefits, there are certain disadvantages of online services that can affect the dissatisfaction of users of various services.

If users are not enough familiar with computers and new technologies, have no previous experience and they may be dissatisfied. In that case, companies face challenges such as setting simpler procedures and providing additional guidelines for using and implementing online services in order to influence ultimate satisfaction of their users.

This paper presents some of the services that were of great importance in the period behind us and refer to services in both the private and public sectors.

As a country in the process of negotiations for accession to the European Union, the Republic of Serbia is harmonizing its eGovernment development strategies with European Union regulations. Since the eGovernment was launched until today, there has been a notice- able increase in the number of users, as well as the expansion of the range of services of state authorities that are available to users. Also, a positive trend of ranking Serbia by the quality of eGovernment is noticeable. In order to maintain and improve its current position, it is necessary to continuously develop and improve its services, but also to inform the population about all benefits and educate them about the self-use of various services within the eGovernment. eBusiness enables several times faster way of doing business than usual, greater adaptability to market changes, more precise and easier access to information on the state of the company, lower costs for material and postal services and thus lower costs of manual labour.

Changes are inevitable, and it is up to companies to adapt to the changes and see them as a chance to further improve their business. Recommendations for further research would be to examine the satisfaction of users of electronic services and to monitor the trend of further development of electronic services in both the public and private sectors. Also, attention can be paid to the analysis of new electronic services that emerged during the global crisis caused by the spread of COVID- 19 .

\section{REFERENCES}

[1] S. Stanišić, "Razvoj i uticaj elektronskog poslovanja na poboljšanje usluga u bankarskom sektoru," in Sinergija, Bijeljina, 2017.

[2] "Sl. glasnik RS", br.94/2017, Zakon o elektronskom dokumentu, elektronskoj identifikaciji i uslugama od poverenja u elektronskom poslovanju, 2019.

[3] I. Stojanović, Elektronska trgovina i kupovina putem Interneta u Srbiji, 2011.

[4] "Sl. glasnik RS" br.51/2010, Strategija razvoja informacionog društva u Republici Srbiji do 2020. godine, 2020.

[5] Statista, "Serbia: Share of economic sectors in the gross domestic product (GDP) from 2008 to 2018," [Online]. Available: https://www.statista.com/statistics/440654/share-of-economic-sectors-in-the-gdpin-serbia/. [Accessed 28 april 2020].

[6] K. N. L. Roland T. Rust, "E-Service and the Consumer," International Journal of Electronic Commerce, pp. 85-101, 2014.

[7] J. E. Bateson and K. D. Hoffman, Marketing usluga, Beograd: Data Status, 2013.

[8] S. Chandrasekaran and M. Narayanan, "Recent and future trends in e-banking services for Indian banking sector," Journal of The Gujarat Research Society, vol. 21, no. 16, pp. 245-251, 2019. 
[9] S. A., J. C. and A. M., "How do electronic word of mouth practices contribute to mobile banking adoption?," Journal of Retailing and Consumer Services, vol. 52, 2020.

[10] Službeni glasnik Republike Srbije, "Zakon o elektronskoj upravi," Narodna skupština , [Online]. Available: www.parlament.gov.rs/upload/archive/ files/cir/pdf/zakoni/2018/164-18.pdf. [Accessed 22 July 2020].

[11] "Kancelarija za informacione tehnologije i elektronsku upravu," [Online]. Available: https://www.ite.gov. rs/tekst/sr/77/portal-euprava.php. [Accessed 22 July 2020].

[12] "Program razvoja elektronske uprave u Republici Srbiji za period od 2019. do 2022. godine i Akcioni plan za njegovo sprovođenje," 24 july 2020. [Online]. Available: http://mduls.gov.rs/wp-content/ uploads/Program-razvoja-e-uprave-za-period-od2019-do-2022.pdf.
[13] UN E-Government Knowledgebase, "E-Government Development Index (EDGI)," [Online]. Available: https://publicadministration.un.org/egovkb/ en-us/About/Overview/-E-Government-Development-Index. [Accessed 24 July 2020].

[14] Službeni glasnik Republike Srbije, "Zakon o ugostiteljstvu," [Online]. Available: http://www.parlament.gov.rs/upload/archive/files/cir/pdf/zakoni/2019/3154-18.pdf. [Accessed 22 July 2020].

[15] Ministarstvo trgovine, turizma i telekomunikacija, "Centralni informacioni sistem u oblasti ugostiteljstva i turizma," [Online]. Available: https:// www.eturista.gov.rs/extfile/sr/331534/eTurista\%20 ppt1.pdf. [Accessed 22 July 2020].

[16] Ministarstvo trgovine, turizma i telekomunikacija, "eTurista," [Online]. Available: https://www.eturista. gov.rs/vest/331570/odlozeno-pokretanje-eturistecentralnog-informacionog-sistema-u-oblasti-ugostiteljstva-i-turizma.php. [Accessed 25 July 2020]. 